\title{
39
}

\section{Court Records as Archives: The Need for Law Reform to Ensure Access}

\author{
Andrew Henderson and Kim Rubenstein ${ }^{1}$
}

\section{Introduction}

Since its establishment in 1976, the Federal Court of Australia (the Federal Court) has served as a site for the disputation, negotiation and resolution of issues fundamentally important to Australian society. It does so in the context of Australia's constitutional system that adheres to the rule of law and open justice, in order to enforce the rights of individuals and navigate the boundaries of the powers of the state. As a 'superior court of record', ${ }^{2}$ the court's collected case files constitute a permanent record of the proceedings before it.

1 Professor Rubenstein, ANU College of Law, is the lead CI on the ARC Discovery Project DP130101954 that this chapter draws upon. Andrew Henderson is a sessional staff member of The Australian National University College of Law and has been employed as a Research Assistant on this project. His co-authorship of this chapter is testament to his own significant contributions to the research output.

2 Federal Court of Australia Act 1976 (Cth) s 5(2). Superior Courts of Record make decisions that are determinative, and their proceedings must be recorded. The High Court of Australia is also a Superior Court of Record. The High Court's records have been identified for many years as items for 'permanent retention'. This has not occurred until very recently for the Federal Court. Unlike the State Supreme Courts, the Federal Court is a Chapter III court, which gives it a greater degree of prominence with an Australian judiciary. Its statutory jurisdiction, particularly in relation to judicial review, also means that it deals with matters directly connected to the relationship between the individual and the state to an extent that is simply not shared with the Supreme Courts. 
The unique role of the Federal Court means that its records speak directly to an individual's relationship with the state and identity as a citizen. ${ }^{3}$ When resolving disputes between parties (whether between individual citizens or between a citizen and the state), the Federal Court inevitably has an impact beyond those parties, through the democratic values it espouses and pronounces, the methods of administrative and judicial decision-making undertaken, as well as its engagement as one arm of government in our constitutional make-up. The documents are also rich records of public interest and importance about the relationship between the individual and the state that are not readily accessible elsewhere. However, the public is restricted to accessing only those documents identified as constituting the 'court record'.

The definition of the 'court record' within an Anglo-Australian tradition of precedent ${ }^{4}$ is a narrowly defined set of materials and the Federal Court's Rules concerning the public inspection of documents mirror this approach. ${ }^{5}$ The importance of the Federal Court's records, however, extends beyond traditional ideas about the 'court record'. We argue that the records constitute a legal, social and cultural archive documenting how individuals and the state have sought to describe and resolve their relationship with one another. The use of the term 'archive' here is not restricted to the common or popular concept of purely historical material or matters simply of historical interest. ${ }^{6}$ Over time, the term 'archive' has come to have a range of meanings. Conventionally understood as a collection of records produced by an individual or organisation and housed in a repository, more recently it has been reconceptualised. Today, an archive may be any record that has value as authentic evidence of administrative, corporate, cultural and intellectual activity. ${ }^{7}$ In this broader context, we argue that the court's contemporary records, including its

3 We are using the term citizen here both in the formal sense of someone who is recognised as a capital 'C' citizen under the Australian Citizenship Act 2007 (Cth), but also the broader normative small ' $c$ ' citizen, being an individual who is a member of the Australian community (i.e. a permanent or temporary resident and not a formal citizen) who has engaged with the State and become an active 'c'itizen in relying on laws to defend his/her rights. For a further discussion about the different meanings of citizenship in Australia, see Kim Rubenstein, Australian Citizenship Law (Thomson Reuters, $2^{\text {nd }}$ edn, 2016) Ch 1.

4 The notion of the 'Record' is a complicated legal concept for the purpose of judicial review. See further Kirk v Industrial Court of NSW (2010) 239 CLR 531 and Craig v South Australia (1995) 184 CLR 163.

5 Federal Court Rules 2011 (Cth), r 2.32(2).

6 Francis X Blouin Jr and William G Rosenberg, Processing the Past: Contesting Authority in History and the Archives (Oxford University Press, 2011), 4.

7 Australian Society of Archivists, Made, Kept and Used: Celebrating 30 Years of the Australian Society of Archivists (2005). 
records of how it manages its own business, provide an account of how parties, including the state, describe rights and responsibilities today, in the here and now, as well as in the past. These perspectives can inform current debates over our roles and identities as citizens.

This chapter draws on an example from a much larger survey of files held by the National Archive of Australia about the Federal Court and identified as part of the Australian Research Council-funded project, The Court as Archive: Rethinking the Institutional Role of Federal Superior Courts of Record. ${ }^{8}$ It argues that the current limits on the court's public access, based on historical concepts of the 'court record', require review and are a potential site of law reform in Australia. This law reform should ensure that the public access principles better reflect deeper understandings of the role and significance of the Federal Court and its records as an archive of value to Australian society.

\section{The Federal Court in Context}

Proceedings before the Federal Court can hold deep significance for the parties and the wider community. For example, the making of orders under the Administrative Decisions (Judicial Review) Act 1977 (Cth) may represent protection from unlawful executive action. The making of orders under the Native Title Act 1993 (Cth) may represent the recognition of deeply held spiritual and cultural connections to the land. For the legal profession in a common law system, judgment might represent a statement of what the law is - with an eye to appeal if the statement is perceived to be wrong. Moreover, Court judgments provide the opportunity to critically assess the performance of the courts and judges in terms of timeliness or even the extent to which they are 'in touch' with the community.9

It is this process of determining a dispute between two or more parties that is the basis of the jurisdiction of a Chapter III court ${ }^{10}$ and represents the core characteristic of Commonwealth judicial power. ${ }^{11}$ However,

8 Discovery Project DP130101954, purl.org/au-research/grants/arc/DP130101954. Associate Professor Ann Genovese from the University of Melbourne and Dr Trish Luker from the University of Technology Sydney have been fellow CIs on the project.

9 Murray Gleeson, 'Out of Touch or Out of Reach?' (2006) 7 The Judicial Review 241, 241.

10 In re Judiciary and Navigation Acts (1921) 29 CLR 257, 266 (Knox CJ, Gavan Duffy, Powers Rich and Starke JJ).

11 Huddart, Parker \& Co Pty Ltd v Moorehead (1909) 8 CLR 330, 357 (Griffith CJ); see also James Stellios, 'Reconceving The Separation Of Judicial Power' (2011) 22 Public Law Review 113, 117. 
in a common law system reliant on precedent both as a body of law and a tool of statutory interpretation, the effects of judicial decision-making are not bound in space or time but may be felt well beyond individual disputes. ${ }^{12}$ The application of a body of law derived from principles and precedent provides continuity, consistency and certainty in individuals' relationships with one another and with the state. ${ }^{13} \mathrm{~A}$ decision may also reach back in time to either affirm or reject previous interpretations of the law or redefine legal and personal relationships. ${ }^{14}$ Through their reasons for decision, Courts reinforce the acceptance of certain ideas while rejecting or disapproving of others. ${ }^{15}$ In this sense, Courts play an important role in understanding ideas of identity, belonging, citizenship and rights.

\section{The Court as Archive}

The focus of lawyers tends to be on the court's record as its end product - orders, reasons and judgment. Reliance on reasons alone is the study of precedent - what has been referred to as 'lawyers' history'. ${ }^{16}$ Reasons for decision provide a summary of the facts 'ascertained' by the court and identified as legally significant. ${ }^{17}$ In effect, the reasons present a narrow set of facts viewed through a particular lens. ${ }^{18}$

Insistence on a precedential or procedural definition of 'the record' ignores the record's much more significant value as an archive. Materials presented by the parties provide both the canvas and the frame for the decision - they provide the foundation for the decision and describe the broader context within which the decision is made. It is here that Court records arguably hold more value to the researcher as a companion, or even contradictor, to state-run archives.

12 Anthony Mason, 'The Use and Abuse of Precedent' (1988) 4 Australian Bar Review 93. See also traditional ideas of the common law representing common custom and usage in Rupert Cross and J W Harris, Precedent in English Law (Clarendon Press, 1991), 36-37.

13 Ibid. See also Mirehouse v Rennell (1833) 1 Cl. \& F. 527, 546.

14 Oscar G Chase, "'Supreme” Courts and the Imagination of the Real' (2015) 518 New York University Public Law and Legal Theory Working Papers, 14.

15 Ibid.

16 Kinvin Wroth, 'Documents of the Colonial Conflict: Part I - Sources for the Legal History of the American Revolution' (1976) 69 Law Librarians Journal 277.

17 Michael McHugh, 'Judicial Method' (1999) 73 Australian Law Journal 37.

18 Clifford Geertz, Local Knowledge: Further Essays in Interpretive Anthropology (Basic Books, 2008), 173. 
Postmodern critiques of archives argue that, to the extent archival institutions are created by, and contain records of, the state, they give primacy to a representation of the community constructed by the state and exclude contradictory voices. ${ }^{19}$ Archives are no longer assumed to be an authoritative source of historical knowledge, but are rather understood to create history through the selection, organisation and provision of documents. ${ }^{20}$ In the context of the individual's relationship with the state, state-run archives therefore might exclude or explicitly devalue or discredit voices of protest. Within the court's own records, contradictory voices are not just heard but are explicitly required. The evidence and other materials submitted to the court are representative of the voices of those who submitted them. They do not contain just one version of a series of events but may contain two or multiple stories told in different ways and from different perspectives. Within this account are cultural and social assumptions - both explicit and implicit - that provide an insight into those relationships. Perhaps even more crucially these are snapshots of assumptions in conflict - of contested ideas about what is acceptable. This more complete archive begins to explain 'not only what went on in the law's formal processes, but what were the full ... effects that law and the life environing the law had on each other'. ${ }^{21}$

The records of one Mrs Law's dispute with the Repatriation Commission provide a specific example of this idea of a more complete archive. The National Archives of Australia (NAA) retains a series of files from various Commonwealth departments ${ }^{22}$ and the Cabinet ${ }^{23}$ concerning proceedings brought by the Commonwealth challenging the award of a war widow's pension to Mrs Law. James Law, Mrs Law's husband, passed away from lung cancer in late 1976. During World War II he began to smoke heavily - a habit he did not quit until a heart attack three

19 Blouin and Rosenberg, above n 6, 159; Ciaran B Trace, 'What is Recorded is Never Simply "What Happened": Record Keeping in Modern Organizational Culture' (2002) 2 Archival Science 137. See also s 2A of the Archives Act 1983 (Cth) and the definition of 'archival resources of the Commonwealth'.

20 Jacques Derrida, Archive Fever (University of Chicago Press, 1996); Carolyn Steedman, Dust: The Archive and Cultural History (Rutgers University Press, 2002).

$21 \mathrm{~J}$ Willard Hurst, 'Legal Elements in United States History' in Donald Fleming and Bernard Bailyn (eds), Perspectives in American History (Little Brown Books, 1971) Vol 2, 3.

22 National Archives of Australia: Prime Minister's Department - Correspondence files; A1209, Appeals to Federal Court for War Widows Pension 1980-1982, 1980/558 PART 1.

23 National Archives of Australia: Fraser Ministries - Cabinet Memoranda; A12930, Memorandum No 639: Law v Repatriation Commission appeal to full court of the Federal Court of Australia Related to Decision No 11094 1980, 639. 
years before his death. After her husband's death, Mrs Law applied for a war widow's pension, arguing her husband had died as a result of an 'occurrence' during his enlistment. The Repatriation Commission did not agree. Mrs Law was successful on appeal before Justice Toohey, then of the Federal Court, ${ }^{24}$ and again when the Commission appealed to the Full Court of the Federal Court ${ }^{25}$ and the High Court. ${ }^{26}$

The proceedings ultimately affected how the then Repatriation Commission would determine more broadly the claims for death or disability concerning ex-service personnel contracting lung cancer from smoking at the time, and into the future. ${ }^{27}$ These files provide some insight into how the state perceived its relationship with its citizens. The files tell a story not apparent from the reasons for decision. Although they opposed Mrs Law's application, Cabinet agreed to meet Mrs Law's costs of the litigation, to continue to pay her pension pending the outcome of the appeal and to investigate other benefits to which she may be entitled. ${ }^{28}$ The Commonwealth's agreement to pay Mrs Law's pension creates the impression of magnanimity and generosity - a positive depiction that arguably speaks to larger ideas of how government should be run. A closer reading of the Cabinet Submission recommending the ongoing payment of the pension, however, reveals a discussion of how the government might be perceived, raising a 'general question of whether, as a matter of public policy an appeal against decisions involving a war widow ... should proceed'. ${ }^{29}$ Among other factors, Cabinet was invited to consider how the Commonwealth's appeal might affect its relationship with the community, noting that an appeal 'would almost certainly produce a very unfavourable reaction from ex-service organisations from which Government has already criticism over the adoption of policies which eroded repatriation benefits'. ${ }^{30}$

We can review a rich range of material in the NAA due to the agency's choice of materials to be kept, which help us understand the relationship between the individual and the state and indeed more about how the state

24 Law v Repatriation Commission (1980) 29 ALR 64.

25 Repatriation Commission v Law (1980) 31 ALR 140.

26 Repatriation Commission v Law (1981) 147 CLR 635.

27 See Judith E Grbich, 'Repatriation Disability Pensions: Reverse Onus of Proof Problems and the Determination and Review System' (1984) 10 Monash University Law Review 73.

28 Above $\mathrm{n} 24$.

29 Above $\mathrm{n} 24$.

30 Above n 24. 
perceived itself. But these do not necessarily create a complete picture, as they are determined by the agency responsible for the litigation, not the Federal Court itself.

\section{Telling the Whole Story: Court Records and Archives}

If we understand the Federal Court's records as an archive, we are immediately presented with a number of inconsistencies and questions, many of which are confronted by this project.

Court records are excluded from the operation of the Archives Act unless specific arrangements are made in consultation with the Chief Justice. ${ }^{31}$ From the perspective of the constitutional principle of separation of Commonwealth judicial power, this may be appropriate. For the legislature to seek to define and direct a Chapter III court concerning the management of its records - particularly those related to the judicial process - may raise questions of interference.

Commonwealth courts have instead sought to address what constitutes their records through their Rules. The position is approached not from the perspective of preserving important materials, but from the traditional, procedural perspective. It is also done inconsistently between the courts themselves. ${ }^{32}$

Between the NAA and the Federal Court, there are further inconsistencies concerning access to materials and timing that would affect any records of proceedings that might be transferred. Materials accessible today in the Federal Court (e.g. an originating application) may not be accessible at

31 Archives Act 1983 (Cth), ss 19(1), 20(1) and 20(3).

32 At the Commonwealth level, legislation establishing the courts is silent. Consequently, the matter is left to Rules, which are inconsistent across jurisdictions. For example, the High Court Rules require the Registrar to maintain the 'records of the Court' and 'documents filed in the registry' as separate things: High Court Rules 2004 (Cth) rr 4.07.01 and 4.07.02. The Family Law Rules use the phrase 'court record' and, while providing no definition, it appears to include documents filed with the registry and may include correspondence and transcript: Family Law Rules 2004 (Cth) r 24.13 'court document'. The Federal Court Rules adopt a similar distinction to the High Court but refer instead to the 'records of the Registry': Federal Court Rules 2011 (Cth) r 2.31(1). However, a practice note uses 'court file', which extends to all documents filed with the Registry but does not equate it with the record: Federal Court of Australia, Practice Note CM23 - Electronic Court File and Preparation and Lodgment of Documents, 10 July 2014, [3.1], [4.4], [4.5], [5.3] and [5.4]. 
Archives for 21 years. ${ }^{33}$ Conversely, materials not available at any time at the Federal Court may become accessible in 21 years time to anyone who applies to the NAA for access.

The records concerning Mrs Law provide an example of this inconsistency and how the state's records influence how it is perceived. To the extent that the records held by the NAA capture the Commonwealth's position, they reflect a particular, and one-sided, understanding of the dispute. Silent in these records are the voices of Mr and Mrs Law or their family. Silent also are the voices of other ex-service personnel and their families who would be affected by the outcome of the appeals. It is here that the Federal Court's records could transcend the procedural to become a unique archive.

Evidence of those involved in litigation, other than the Commonwealth, may be held by the NAA, but only where a Commonwealth agency considers it sufficiently important to be kept on their file. These broader materials, developed for the purpose of litigation, form a fundamental element of the judicial process before the Federal Court. Making the materials - which may not exist anywhere else - available begins to tell a more complete story about not only $\mathrm{Mr}$ and Mrs Law, but also about individual citizens' expectations of and relationships with the state.

\section{Conclusion}

Developments within the Federal Court itself, compelled by its discussions with the NAA, reflect a realisation of the importance of the materials it controls. In October 2011, the NAA endorsed the Federal Court's Records Authority for the management and disposal of the court's records. ${ }^{34}$

Certain classes of case file have been identified in the Records Authority as so important that their entire contents are to be permanently retained by NAA, namely, all native title files and 'significant, non-native title files'. While the criteria for determining 'significance' continue to be developed, its inclusion as a basis for identifying records for permanent retention reflects the court's understanding of its role beyond a mechanism for dispute resolution.

33 Archives Act s 31(1).

34 Records Authority 2010/00315821 - Federal Court of Australia, 19 October 2011. 
However, the Records Authority applies only to files to be transferred to the NAA. The existing statutory bar on public access to materials held by the NAA will continue to apply, placing those records beyond public access for many years to come. The records that the Federal Court holds are of both historical importance but also of importance today. Limited access places the public in a position of disadvantage in understanding how the state perceives its role and responsibilities. It is also inconsistent with our understanding of open justice and transparency. It is a matter in need of reform. 
This text is taken from New Directions for Law in Australia: Essays in Contemporary Law Reform, edited by Ron Levy, Molly O’Brien, Simon Rice, Pauline Ridge and Margaret Thornton, published 2017 by ANU Press, The Australian National University, Canberra, Australia. dx.doi.org/10.22459/NDLA.09.2017.39 